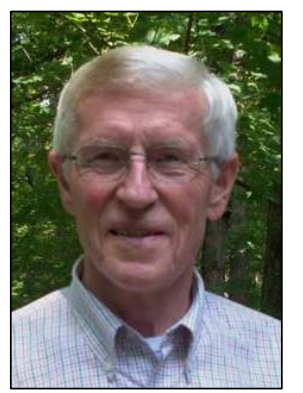

\author{
THE ECONOMic PAMPhleteer \\ JOHN IKERD
}

\title{
Zoning considerations for urban and peri-urban agriculture
}

Citation: Ikerd, J. (2010, November). Zoning considerations for urban and peri-urban agriculture. Journal of Agriculture, Food Systems, and Community Development, 1(2): 5-7. doi:10.5304/jafscd.2010.012.001

Copyright (C) 2010 by New Leaf Associates, Inc.

Every year, about 1.2 million acres of U.S. farmland is converted to residential and other commercial uses, according to the American Farmland Trust. ${ }^{1}$ This includes some of the most fertile farmland in the nation, as many of our major cities

Why did I name my column "The Economic

Pamphleteer"? Pamphlets historically were short, thoughtfully written opinion pieces and were at the center of every revolution in western history. Current ways of economic thinking aren't working and aren't going to work in the future. Nowhere are the negative consequences more apparent than in foods, farms, and communities. I know where today's economists are coming from; I have been there. I spent the first half of my 30-year academic career as a very conventional freemarket, bottom-line agricultural economist. I eventually became convinced that the economics I had been taught and was teaching wasn't good for farmers, wasn't good for rural communities, and didn't even produce food that was good for people. I have spent the 25 years since learning and teaching the principles of a new economics of sustainability. Hopefully my "pamphlets" will help spark a revolution in economic thinking.

\footnotetext{
1 American Farmland Trust, http://www.farmland.org/programs
}

were originally established in fertile farming areas. With more than 900 million acres of farmland remaining, we are not likely to run out of land for farming in the near future. However, farmland conversion is clearly putting the long-run sustainability of U.S. food production at risk.

Our current industrial food system is critically dependent on cheap fossil energy for fertilizer, machine operation, irrigation, and food manufac-

\footnotetext{
John Ikerd is professor emeritus of agricultural economics, University of Missouri, Columbia. He was raised on a small dairy farm in southwest Missouri and received his $B S, M S$, and Ph.D. degrees in agricultural economics from the University of Missouri. He worked in private industry for a time and spent 30 years in various professorial positions at North Carolina State University, Oklahoma State University, University of Georgia, and the University of Missouri before retiring in 2000. Since retiring, he spends most of his time writing and speaking on issues related to sustainability with an emphasis on economics and agriculture. Ikerd is author of Sustainable Capitalism; A Return to Common Sense; Small Farms Are Real Farms; Crisis and Opportunity: Sustainability in American Agriculture; and, just published, A Revolution of the Middle. More background and selected writings are at http://web.missouri.edu/ ikerdj.
} 
turing, transportation, and retailing. Industrial agriculture is also a major contributor to growing environmental problems. Although estimates vary, food production in the U.S. may account for up to $20 \%$ of all fossil energy use and something more than $20 \%$ of all greenhouse gas emissions. In addition, agriculture is the number one nonpoint source of pollution of U. S. rivers and lakes. ${ }^{2}$ With dwindling fossil energy supplies and rising environmental concerns, every acre of fertile farmland lost to development becomes more precious each year.

The local foods movement presents a prime opportunity to address the problem of farmland conversion. Producing more of our food in and near major population centers would obviously preserve fertile farmland for future food production. People also become more aware of their inherent connectedness to the land when they live on or near farms. Thus, commercial farming in urban and peri-urban areas should encourage the transition from industrial to sustainable systems of farming and food production. However, as farms and residences increasingly rub shoulders, farms in urban and peri-urban areas will need to be "peoplefriendly" farms.

Many of the current conflicts associated with farming in urbanizing areas arise from industrial farming practices, such as aerial pesticide application and confinement animal feeding operations. ${ }^{3}$ Many residents in peri-urban areas logically refuse to be subjected to a daily dose of noxious odors or even an annual dose of toxic pesticides. In densely populated urban areas, the nuisance and health

\footnotetext{
${ }^{2}$ U.S. Environmental Protection Agency, Managing nonpoint source pollution from agriculture, Pointer No. 6, EPA841-F-96004F, http://water.epa.gov/polwaste/nps/outreach/ point6.cfm

3 American Farmland Trust, Sustaining farms on the urban edge, http://www.farmland.org/resources/sustaining-agriculture-inurbanizing-counties
}

risks associated with industrial agriculture would be even less tolerable.

On the other hand, farms that use organic or other sustainable farming practices are good places to live on and live around. Anyone willing to adapt to life in the country would enjoy living next door to a sustainable farmer or even in a cluster development with residences strategically placed to accommo-

date the farming operation. Sustainable urban "farms" - on rooftops, in backyards, or on neighborhood farmparks-would generate fewer odors, less noise, and fewer health risks than the garbage, traffic, and other daily perils of urban living. However, those who produce food in urban and peri-urban areas must accept restrictions in their choices of enterprises to accommodate the preferred lifestyles of nearby residents.

Land is inherently a "public good" and must be used in ways that benefit the common good of society in general. This does not deny private property rights, which have always been limited rights of land use rather than absolute rights of land ownership. Zoning is a common means of limiting uses of private property. For example, people living in areas zones as "residential" cannot use their property for most commercial purposes. Even areas zoned "commercial" may be restricted as to what types of businesses may be operated, depending on their proximity to private residences, housing developments, schools, churches, or other noncommercial uses.

Zoning is a process by which the public, in essence, grants permission to landowners to use their land for certain limited purposes. Rezoning likewise requires public permission to change land uses. Rezoning may be done with or without the permission of the landowner. Private property rights are not absolute. They are granted by and 
may be revoked by the public through due processes of law.

Historically, agriculture has been exempt from many of the land use restrictions that apply to other types of commercial operations. Right-to-farm laws have exempted farmers from nuisance laws as long as they use "accepted and standard" farming practices, even in cases where such practices are detrimental to nearby property owners or the general public. ${ }^{4}$ The exemptions typically include noise, odors, visual clutter, and dangerous structures. Every state has some form of a right-tofarm law.

Right-to-farm laws became common in the U.S. during a time when a large segment of the population lived on a farm, had grown up on a farm, or had some direct knowledge of farm life. Farming was an accepted way of life and could not be deemed a nuisance legally by those who didn't understand it. Perhaps most important, farming was very different from other commercial land uses. Farming at the time generally didn't involve heavy applications of toxic liquids and poisonous gasses, constant loud noises, or even significant exposure to noxious odors.

Today, right-to-farm laws are being challenged in the courts because today's large industrial farming operations are more like industry than agriculture. Fifty years of socioeconomic studies have verified that industrial agriculture not only diminishes property values and the quality of life of its neighbors, but also degrades the social and economic

well-being of communities in which it becomes commonplace. ${ }^{5}$ For example, the one thing on which advocates and opponents of large-scale confinement animal feeding operations seem to agree is the dissention these CAFOs invariably create in communities

where they attempt locate.

If food production is to become commonplace in urban and urbanizing areas, agriculture must accept the same types of restrictions as are common for other land uses. Zoned uses for "urban agriculture," for example, might be limited to organic, bio-intensive, and other methods appropriate in densely populated areas. Most types of sustainable agriculture could be allowed on land zoned for peri-urban agriculture. Typical agriculture zoning and right-to-farm laws would be limited to traditional family farming operations. Industrial agriculture should be subject to the same zoning restriction and nuisance laws as any other industrial operation. If farmers resist reasonable land-use restrictions, food production will continue to be zoned out of urban and peri-urban areas.

\footnotetext{
${ }^{5}$ Stofferahn, C. (2006, September). Industrialized Farming and Its Relationship to Community Well-Being: An Update of a 2000 Report by Linda Lobao, report prepared for the State of North Dakota, Office of the Attorney General, http://www.und.edu/org/ ndrural/Lobao $\% 20 \& \% 20$ Stofferahn.pdf
}

\footnotetext{
${ }^{4}$ Wikipedia On-Line Encyclopedia, http://en.wikipedia.org/wiki/Right-to-farm laws
} 
Journal of Agriculture, Food Systems, and Community Development ISSN: 2152-0801 online www.AgDevJournal.com 